\title{
China's Service Trade and Service Industry Growth - An Empirical Analysis from the Aspect of Factor Intensity
}

\author{
Ke Xuan
}

School of Economics and Management, Beijing Jiaotong University, Haidian District, Beijing, China 14120544@bjtu.edu.cn

Keywords: Service industry growth, Service imports and exports, Factor intensity, VEC model.

\begin{abstract}
China's service industry has grown rapidly since 1997, and meanwhile the service imports and exports also increased at a great speed, indicating a link between China's service trade and service industry GDP. This paper separates services into three categories by factor intensity and conducts an empirical analysis with vector error-correction (VEC) models. The results find that there is a long-run relationship among China's service industry outputs, labor-intensive service trade, capital-intensive service trade and knowledge-intensive service trade. Among the three types of services, only labor-intensive service exports, capital-intensive imports and knowledge-intensive imports have an impact on the growth of China's service industry.
\end{abstract}

\section{Introduction}

With the growth of service trade exceeding the growth of trade in goods gradually, many countries came to focus on the international trade in services in the 1980s. According to China Service Trade Development Report, China's service exports increased from 24.5 billion USD in 1997 to 222.2 billion USD in 2014, and service imports increased from 27.7 billion USD in 1997 to 382.1 billion USD in 2014. Meanwhile, China's service industry is growing rapidly, and China's industry structure is shifting from agriculture and manufacturing to service due to the huge growth potential of the service industry.

According to the factors of production, services can be divided into three categories, i.e. capital-intensive services, labor-intensive services and knowledge-intensive services. Capital-intensive services include transportation services, telecommunication services and building services; labor-intensive services include travel services, and knowledge-intensive services include financial services, computer and IT services, insurance services, consulting services, patent services, advertising services, etc. Figure 1 presents the amount of exports and imports of the three categories in China from 1997 to 2014 respectively. The growth rate of knowledge-intensive service exports exceeded that of labor-intensive service exports after 2006. Labor-intensive service exports growth slowed down from 2008 as a result of the increasing wages in China, while its imports kept increasing more and more rapidly. As for capital-intensive service, its import and export increased slowly and steadily in the past score.

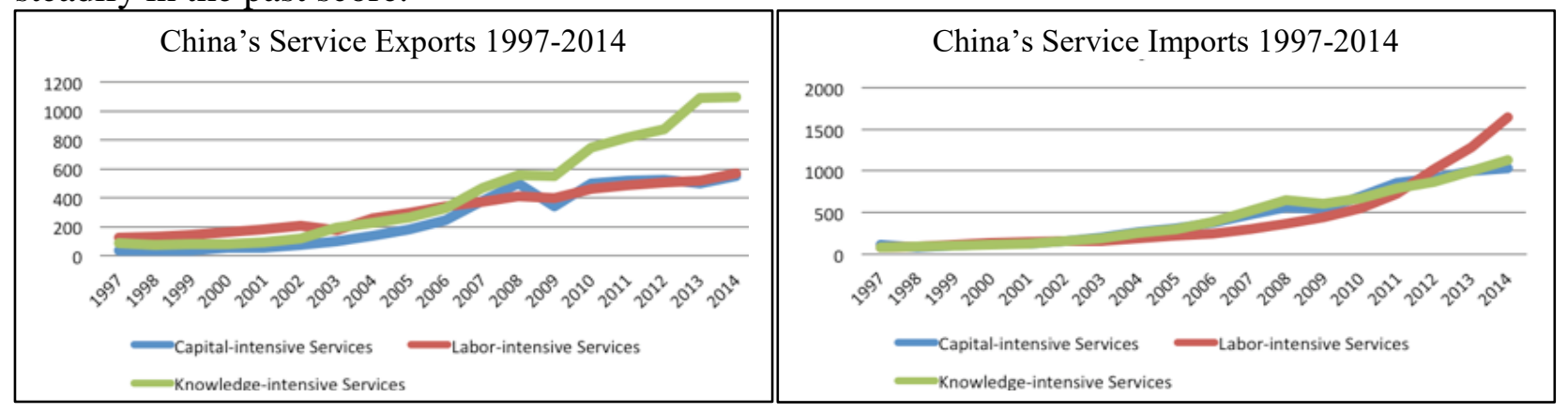

Fig. 1. China's Service Exports and Imports 1997-2014 (Unit: 100 million USD, Source: Ministry of Commerce of the P.R. China). 
China's service industry has grown rapidly, form 2781.09 billion RMB in 1997 to 30603.82 billion RMB in $2014^{1}$. As the service industry GDP increases with the growth of service trade, the relationship between service growth and service trade is worth studying. This paper is designed to investigate the relationship between the growth of China's service industry and service trade, from a deeper and more detailed aspect, i.e. the factor intensity. The following hypotheses are examined: (1) there is a cointegration relationship and causality between service industry growth and service imports; (2) there is no significant relationship between service industry growth and service exports except labor-intensive service exports; (3) labor-intensive service imports and exports, knowledge-intensive imports and capital-intensive imports Granger cause service industry growth but other service imports/exports do not.

\section{Literature Review}

The study of international trade began in the 1970s. With a lot research on the relationship between trade and growth published, it has been universally acknowledged that international trade contributes to economic growth. From the late 1990s, many scholars began to study the trade in services because of the huge growth potential of the service industry. At the beginning, the service industry was not so diverse as it is today, and growth theory even accords no special role to service activities, with the exception of financial services (Hoekman and Mattoo, 2008). Francois and Schuknecht (1999) conduct research on the trade in financial services. This research finds that the openness in financial services increases the competition of this industry and leads to industrial growth. In the 21 st century, there are more studies of trade in diverse services. El Khoury and Savvides (2006) examine the different influence of trade in services on developing and developed economies. The study concludes that low-income countries benefit more from the openness in telecommunication services while the high-income economies from financial services openness. According to this finding, China's economic growth should benefit more from capital-intensive services. Both of the two studies indicate the contribution of service trade to the growth. Huiqin Zeng (2009) argues that both of the imports and the exports of services stimulate the growth of service industry, while the service exports have a greater influence than the service imports. Shuli Wang and Zongbiao Hu (2009) also show that service exports Granger cause the growth of service economy, but service economy does not Granger cause the service imports.

According to these conclusions, service trade, especially service export shows a significant influence on both economy growth and service industry growth. However, none of the previous studies analyzed the influence of service trade on service industry growth from the aspect of factor intensity. Thus, this paper studies the service exports and service industry growth in China and also divides the service exports into three categories, according to factor production, to study the relationship between the service industry growth and each category, which is an innovation.

\section{Empirical Methodology and Data}

The samples in this paper are quarterly time series data from 1997 to 2014, collected from China Statistical Yearbook 2014-2015 and China Service Trade Development Report 2013. There are 7 variables and 72 observations. All of the variables are deflated by the consumer price index $(1978=100)$. Table 1 shows summary statistics of each variable without logarithm.

\footnotetext{
${ }^{1}$ Data source: National bureau of statistics of China, China Statistical Yearbook 2015, China Statistics Press, 2015.
} 
Table 1 Summary Statistics of the Variables [Billion USD]

\begin{tabular}{llllll}
\hline Variable & Label & Mean & SD & Max & Min \\
\hline SGDP & service industry GDP & 30205.06 & 18835.15 & 69658.22 & 7978.37 \\
\hline SCEX & capital-intensive service exports & 67.42 & 46.72 & 131.26 & 11.10 \\
\hline SLEX & labor-intensive service exports & 82.88 & 30.35 & 131.16 & 36.40 \\
\hline SKEX & knowledge-intensive service exports & 107.56 & 77.56 & 251.31 & 23.04 \\
\hline SCIM & capital-intensive service imports & 110.71 & 71.38 & 229.14 & 24.26 \\
\hline SLIM & labor-intensive service imports & 107.57 & 95.98 & 396.90 & 23.71 \\
\hline SKIM & knowledge-intensive service imports & 113.67 & 73.85 & 261.17 & 23.71 \\
\hline
\end{tabular}

The specification used in this paper is vector autoregressive (VAR) model. However, if there is cointegration, an error correction term should be added to the model to avoid spurious regression, and thus the specification should be changed to vector error-correction (VEC) model. In this paper, there are two specifications. When examine the relationship between service exports and service industry growth, the paper uses Eq. 1, while when examine the relationship between service imports and service industry growth, the paper uses Eq. 2. To avoid the problem of heteroskedasticity, all the variables are expressed in a logarithmic form.

$$
\begin{aligned}
& \ln S G D P={ }_{0}+{ }_{1} \ln S C E X+{ }_{2} \ln S L E X+{ }_{3} S K E X+u_{1} . \\
& \ln S G D P={ }_{0}+{ }_{1} \ln S C I M+{ }_{2} \ln S L I M+{ }_{3} S K I M+u_{2} .
\end{aligned}
$$

To estimate the parameters of the models, augmented Dickey-Fuller (ADF) test, Cointegration tests and Granger Causality are adopted in this paper.

\section{Empirical Results}

4.1. Stationary. The augmented Dickey-Fuller test was developed to check the stationary of time series data. This paper uses ADF test and graphical analysis to check the stationarity of each variable. According to the results, all of the variables are found to be non-stationary, but the first difference of these variables are stationary, so the variables are all I(1). The results of ADF test are shown in table 2 .

Table 2 ADF Test Results

\begin{tabular}{lll|lll}
\hline Variable & ADF statistics & Stationarity & Variable & ADF statistics & Stationarity \\
\hline LSGDP & $-1.78(-2.57)$ & No & $\triangle$ LSGDP & $-4.57(-2.57)$ & Yes \\
\hline LSCEX & $-0.03(-2.57)$ & No & $\triangle$ LSCEX & $-3.44(-2.57)$ & Yes \\
\hline LSLEX & $-0.87(-2.57)$ & No & $\triangle$ LSLEX & $-4.27(-2.57)$ & Yes \\
\hline LSKEX & $-1.04(-2.57)$ & No & $\triangle$ LSKEX & $-3.86(-2.57)$ & Yes \\
\hline LSCIM & $-0.89(-2.57)$ & No & $\triangle$ LSCIM & $-4.27(-2.57)$ & Yes \\
\hline LSLIM & $0.39(-2.57)$ & No & $\triangle$ LSLIM & $-4.4(-2.57)$ & Yes \\
\hline LSKIM & $-1.37(-2.57)$ & No & $\triangle$ LSKIM & $-4.11(-2.57)$ & Yes \\
\hline
\end{tabular}

4.2. Cointegration. As all of the variables are integrated of order one, cointegration relationship should be detected among them. Cointegration tests are used to determine whether variables integrated of the same order are cointegrated. There are two methods for the test. One is the Engle-Granger methodology, and the other is to use the Johansen tests. If the variables are integrated to the same order, then they must be tested for the cointegration relationship (Johansen, 1988).

Engle and Granger developed this method. As Engle-Granger method is based on the ADF test for the residuals from a single cointegration relationship, there are two steps in this method: (1) estimating the long-run (equilibrium) equation; (2) estimating the error correction model (or using the residuals form).

Johansen tests permit more than one cointegration relationship at the same time, so it is more convenient than the Engle-Granger test. According to different likelihood ratio applied, there are also two approaches in Johansen test: the trace test and maximum eigenvalue test. The null hypothesis 
when $r=r_{0}$ is that there is $r_{0}$ cointegration relationship(s). If null hypothesis is rejected at $r=r_{0}$ but accepted at $r=r_{0}+1$, the number of cointegration relationships among the variables is $r_{0}$.

Both of the two testing methods are adopted in this paper.

\subsubsection{Cointegration Between Service GDP and Service Exports}

When using Engle-Granger method, the residuals from the Eq. 1 are extracted for stationarity tests. According to the graphical analysis and the result of ADF test ( $\mathrm{p}$-value $=0.041$ ), the residuals are stationary, indicating there is a cointegration relationship. According to the results of Johansen tests, which are shown in table 3, both of the two approaches indicate there is a cointegration relationship among the four variables at $99 \%$ confidence level.

Table 3 Johansen test Results of Eq. 1

\begin{tabular}{lllllll}
\hline Approach & $\mathrm{H}_{0}$ & Statistics & $10 \mathrm{pct}$ & $5 \mathrm{pct}$ & $1 \mathrm{pct}$ & Conclusion \\
\hline Eigenvalue test & $\mathrm{r}=0$ & 45.55 & 25.56 & 28.14 & 33.24 & Reject \\
\cline { 2 - 6 } & $\mathrm{r}<=1$ & 18.03 & 19.77 & 22.00 & 26.81 & Accept \\
\hline \multirow{2}{*}{ Trace test } & $\mathrm{r}=0$ & 78.22 & 49.65 & 53.12 & 60.16 & Reject \\
\cline { 2 - 6 } & $\mathrm{r}<=1$ & 32.66 & 32.00 & 34.91 & 41.07 & Accept \\
\hline
\end{tabular}

\subsubsection{Cointegration Between Service GDP and Service Imports}

When using Engle-Granger method, the residuals from the Eq. 2 are extracted for stationarity tests. According to the graphical analysis and the result of ADF test ( $\mathrm{p}$-value $=0.049$ ), the residuals are stationary, indicating there is a cointegration relationship. The results of Johansen tests are shown in table 4, according to which both of the two approaches indicate there are two cointegration relationships among the variables in $99 \%$ confidence interval.

Table 4 Johansen test Results of Eq. 2

\begin{tabular}{lllllll}
\hline Approach & $\mathrm{H}_{0}$ & Statistics & $10 \mathrm{pct}$ & $5 \mathrm{pct}$ & $1 \mathrm{pct}$ & Conclusion \\
\hline Eigenvalue test & $\mathrm{r}=0$ & 47.58 & 25.56 & 28.14 & 33.24 & Reject \\
\cline { 2 - 6 } & $\mathrm{r}<=1$ & 27.40 & 19.77 & 22.00 & 26.81 & Reject \\
\cline { 2 - 6 } & $\mathrm{r}<=2$ & 10.68 & 13.75 & 15.67 & 20.20 & Accept \\
\hline \multirow{2}{*}{ Trace test } & $\mathrm{r}=0$ & 88.58 & 49.65 & 53.12 & 60.16 & Reject \\
\cline { 2 - 6 } & $\mathrm{r}<=1$ & 41.00 & 32.00 & 34.91 & 41.07 & $95 \%$ Accept \\
\cline { 2 - 6 } & $\mathrm{r}<=2$ & 13.60 & 17.85 & 19.96 & 24.60 & Accept \\
\hline
\end{tabular}

Thus, there is a cointegration relationship among service GDP and the three types of service exports, and there are also two cointegration relationships among service GDP and the three types of service imports.

4.3. Granger Causality Granger Causality is a method, developed by Granger, for time-series investigation of causality. According to the definition, if a variable $\mathrm{Y}$ can be predicted better by using past values of $Y$ and past or present values of $X$, than using past values of $Y$ alone, then the variable $X$ is a cause of variable Y. In this paper, a vector error-correction model (VECM) is built before testing the Granger causality, because cointegration is detected in the two models. To decide the VAR lag, AIC and BIC are the criteria for the best number of lags selection.

4.3.1 Granger Causality Between Service GDP and Service Exports

The recommended number of VAR lags is 12 according to AIC and 1 according to BIC. As the 1st through 12th lags are insignificant in all of the VAR equations, this paper adopts the number of lags recommended by BIC. As BIC often underestimates the number of lags, this paper keeps one more lag, and the selected model is VAR (2). The results of Granger Causality test are shown in table 5, indicating that labor-intensive service exports and knowledge-intensive service exports Granger cause service GDP at $95 \%$ confidence level. 
Table 5 Granger Causality of Eq. 1

\begin{tabular}{ll|ll}
\hline Variable & P-value & Variable & P-value \\
\hline LSCEX & 0.9215 & LSKEX & $0.008669 * * *$ \\
\hline LSLEX & $0.007805 * * *$ & & \\
\hline
\end{tabular}

\subsubsection{Granger Causality Between Service GDP and Service Imports}

AIC recommends 12 lags while BIC recommends 1 for this VAR model. As most of the lags after the first one are insignificant in all of the four VAR equations, this paper adopts the number of lags recommended by BIC and also keeps one more lag, so the selected model is VAR (2). According to the results of Granger Causality test shown in table 6, only labor-intensive service exports Granger cause the growth of China's service industry.

Table 6 Granger Causality of Eq. 2

\begin{tabular}{ll|ll}
\hline Variable & P-value & Variable & P-value \\
\hline LSCIM & $0.0044 * * *$ & LSKIM & $0.0028^{* * *}$ \\
\hline LSLIM & 0.4422 & & \\
\hline
\end{tabular}

\section{Conclusions}

According to the empirical analysis results, there is a long-run relationship among China's service industry output, labor-intensive service exports, capital-intensive service exports and knowledge-intensive service exports. There is also a long-run relationship among the growth of China's service industry output, labor-intensive service imports, capital-intensive service imports and knowledge-intensive service imports. However, among these three types of service exports, only labor-intensive service exports, capital-intensive imports and knowledge-intensive imports have an impact on the growth of China's service industry, which can be explained by the features of the three types of services. Low labor costs provide China great export opportunities, which accelerate the growth of service industry. Moreover, the imported capital-intensive services and knowledge-intensive services are more advanced than the domestic ones in China, so they contribute to China's service GDP.

A limitation of this study is that some independent variables are not included in the model. This may result in biased estimation and spurious regression. Future studies should consider other relevant determinants in addition to service exports, imports and inflation.

\section{References}

[1] A. C. El Khoury and A. Savvides, Openness in services trade and economic growth, Economics Letters, vol. 92(2), pp. 277-283, 2006.

[2] J. F. Francois and L. Schuknecht, Trade in financial services: Procompetitive effects and growth performance, Social Science Electronic Publishing, 1999.

[3] B. Hoekman and A. Mattoo, Services trade and growth, International Journal of Services Technology \& Management, vol.17(2),pp. 191-199, 2008.

[4] Z. Hu and S. Wang, An Empirical Study on the Joint Development between Service Trade and Service Economy in China: 1985-2006. Journal of International Trade, 2009.

[5] S. Johansen, Statistical analysis of cointegration vectors. Journal of economic dynamics and control, vol.12(2), pp. 231-254, 1988.

[6] H. Zeng, The Influence of Service Trade on Service Industry and Economic Growth - Based on the Cointegration Tests for the Panel Data of OECD countries. Research on Development, vol. 4, pp. 70-73, 2009. 
[7] E. Zivot and J. Wang, Vector autoregressive models for multivariate time series. Modeling Financial Time Series with S-Plus, pp. 385-429, 2006. 